\title{
Clinical and nutritional aspects of cystic fibrosis patients assisted by a home enteral nutrition program in Brazil
}

\author{
Aspectos clínicos y nutricionales de pacientes con fibrosis \\ quística con la asistencia de un programa de \\ nutrición enteral domiciliario en Brasil
}

\begin{abstract}
This study to assessed 47 cystic fibrosis (CF) patients assisted by a program of Home Enteral Nutrition. Anthropometric measurements included weight, height, triceps skinfold thickness, waist circunference and spirometry was also performed. Enzymes, nutritional and fat-soluble vitamin supplementations were recorded. There were no associations with enzymes and vitamin supplements between groups that did or did not have a nutritional deficit. Spirometry of patients without nutritional deficit, utilizing the European and American Consensus, showed that the ratio of FEV1 $\geq 80 \%$ was statistically greater than the ratio of FEV $1<80 \%$ ( $p=0.0459$ and 0.0230 , respectively). The proportion of patients without nutritional deficit was statistically lower in those who use supplements compared to those who did not. than when considers both Consensus ( $p=0.0210$ and 0.0098 , respectively). CF patients with FEV $1<80 \%$ and arm circumference $<5$ th percentile showed statistically significant. The associations between nutritional deficits and altered pattern of spirometry are common situations among CF patients.

Key words: Cystic fibrosis, lung disease, nutritional status, neonatal screening, spirometry.
\end{abstract}

\section{INTRODUCTION}

Cystic Fibrosis (CF) is a genetic disease that leads to pancreatic insufficiency, chronic obstructive pulmonary disease and malnutrition (1). The nutritional state of the patient and the early introduction of preventive therapy have an important relation to the progress of pulmonary diseases, affecting the quality of life and survival of the patients $(2,3)$.

The incidence of CF varies according to ethnicity, being more common among Caucasians (4). The longevity of the patients has increased over the years mainly due to effective treatment and currently studies show the possibility of living more than 50 years for CF patients born after 2000 (5).

In 2009, the Health Secretary of the Federal District, of Brazil, published the first Technical Regulations for Supply of Home Enteral Nutrition (HEN), bringing benefits to patients diagnosed with $C F$, and thus providing a greater access to nutritional therapy and improvements in nutritional and clinical
Adriana Haack (1)

Maria Rita Garbi Novaes (2)

(1) Secretary of Health of the Federal District, Brasilia, Brazil. (2) School of Medicine. School of Health Science, Brasilia, Brazil.

Author responsible for correspondence: MS Adriana Haack SHIGS 715 Bloco A Casa 87 Brasilia-DF, Brasil. CEP $70381-701$ Telephone: 55 (61) 33486200 E-mail: adrianahaack@hotmail.com

Este trabajo fue recibido el 23 de Octubre de 2012 y aceptado para ser publicado el 21 de Enero de 2013. status of these patients, users of the Unified National Health System, in which health is a matter of State and everyone's right $(6,7)$.

Public health policies as the supply of HEN and the Neonatal Screening test of broad access to the population can assist in the early detection of CF and in preventing complications. The costs of applying the benefits are coordinated by the State's budget departments (8).

This study aims to assess the socioeconomic, clinical and nutritional profile of CF patients assisted by a program of HEN in a Cystic Fibrosis Reference Center in Brazil.

\section{SUBJECTS AND METHODS}

This cross-sectional, analytic study was carried out with 47 patients, 2-19 years ( 9.6 mean \pm 4.2 ), from August 2009 to July 2011, all patients of the Home Enteral Nutrition Program (HENP) that was performed in a Cystic Fibrosis Re- 
ference Center of the Federal District, Brazil. Although the Reference Center has 66 registered patients, 14 CF patients were excluded because they were adults who were not accompanied by the same team or in breastfeeding. There were two deaths (one child and a teenager) and 3 refused to participate.

The diagnosis of CF was made according to the Guidelines of the Cystic Fibrosis Foundation (9). The research protocol was based on the patient chart formulated by the service staff of the Reference Center and included socioeconomic, clinical and nutritional data.

According to the World Health Organization classification, adolescents aged from 10 to 19 years were taken into account, and the remaining subjects were considered children.

The weight $(\mathrm{W})$ and height $(\mathrm{H})$ were measured as children and teenagers wore only light clothing and no shoes. It was used a platform-type anthropometric scale, brand Filizola ${ }^{\circledR}$, ranking $100 \mathrm{~g}$ with a maximum capacity of 150 $\mathrm{Kg}$. The height was measured with a stadiometer, accuracy of $0.1 \mathrm{~cm}$ and maximum extension of $2 \mathrm{~m}$, brand Sanny ${ }^{\circledR}$, with the child or adolescent wearing no shoes standing upright with their heels against the wall without a baseboard, staring straight ahead. Measurements of weight and height were used to determine the Body Mass Index (BMI) percentile (11) and $\mathrm{W} / \mathrm{H} \%$ for the definition of acceptable nutritional status ( $>25$ th percentile or $\mathrm{W} / \mathrm{H} \%$ above $90 \%$ ), with risk (10th - 25th percentiles or $\mathrm{W} / \mathrm{H} \%$ 85-89) and nutritional failure (<10th percentile or $\mathrm{W} / \mathrm{H} \%<85$ ) according to the recommendations proposed by the American and European Consensus on CF $(12,13)$.

The measurement of arm circumference (AC) and triceps skinfold thickness (TSF) were observed and analyzed according to standard procedure. The percentiles of AC and TSF $<5$ th show depletion of muscle and adipose tissue, respectively (10). The anthropometric assessment was conducted by a nutritionist at the Center of Reference.

To summarize the statistical analysis of the nutritional status, patients with nutritional failure were referred to as "with nutritional deficit" and those in acceptable nutritional status and at risk (without nutritional failure or invasive nutritional support), were considered "without nutritional deficit".

Spirometry was only performed in children older than 6 years due the difficulty of conducting the examination in young children and the cutoff predicted point was $80 \%$ for height and sex as the lower limit of normality for the parameter of forced expiratory volume in one second (FEV1) (14). The technique of examination followed the recommendation of the American Thoracic Society (ATS) (15) and was held in portable equipment of standardized volume, model Spidaß. The technician responsible for the spirometry was able to evaluate correctly the curves and maneuvers of pulmonary function test.

A nutritionist registered a 24-hour dietary recall (24HDR) the amount of food consumption and distribution of macronutrients ingested the day before the consultation. The 24HDR was analyzed by Avanutri 4.0 software. For the recommendations of energy intake, they were based on guidelines from 120 to $150 \%$ of the established energy for healthy individuals of similar age and sex according to the Recommended Dietary Allowances/DRIs (16).

The Pancreatic Enzyme Replacement Therapy (PERT) and fat-soluble vitamin supplementation were recorded and classified as present or absent. The utilized enzymes were CREON $®$ of 10.0000 units, CREON $®$ of 25.000 units and the vitamin supplement $A D E K s \circledR$.

Data were analyzed using the statistical program SAS 9.2 for Windows. Student $t$ test was used for variables with Gaussian distribution; for those which did not present a Gaussian distribution, the Mann-Whitney test was used. The chi-square or Fisher's exact test was used for the analysis of qualitative variables. In the evaluation, it was used a significance level of $5 \%$.

To evaluate the pulmonary function of cystic fibrosis patients, we used spirometry values. Due to the patient's low social economic situation, in addition to their ages being less than 6 years old, not all patients could go through spirometry, therefore only 37 cystic fibrosis patients' samples were taken into consideration, not 47.

The study was approved by the Ethics Research Comitee of the Health Secretary of the Federal District (Protocol 186/2009). All patients were invited to participate and signed a Free Informed Term of Consent.

\section{RESULTS}

In this study, $59.5 \%$ of the patients were male, and the ages of diagnosis and maternal education were 23.3 months and 11.3 years, respectively. $65.9 \%$ of the patients had a family income of approximately $\$ 464$ (four hundred sixty four United State dollars) and it would be classified as low socioeconomic status in Brazil (table 1).

Due to the low income of the families and the difficult access to specialized exams such as the gene mutation one, within the 47 studied patients, only 10 did the genetic research and all results were positive for the mutation delta F508. Among them, $90 \%$ had pancreatic insufficiency (confidence interval - $\mathrm{Cl} 95 \%, 55,0-99,7$ ) and according to the European and American classification of nutritional condition, $50 \%$ of the patients had nutritional deficit with Cl 95\% (18,71-81,29).

When analyzing the nutritional status in "without nutritional deficit" and "with nutritional deficit," according to the American and European Consensus (12,13), the average age of diagnosis and years of maternal education were not statistically significant as seen by the values of $p=0.5220$ and $p=0.2487$ for European (13), $p=0.3969$ and $p=0.5060$ for American (12). We also found no connection with family income, use of enzymes (PERT) or vitamin supplements between groups who did or did not have a nutritional deficit. In the analysis of spirometry of CF patients "without nutritional deficit", in both Consensus $(13,12)$, it was found that the ratio of FEV $1 \geq 80 \%$ is statistically greater than the ratio of FEV $1<80 \%(0.0459$ and 0.0230 , respectively).

The rate of CF patients "without nutritional deficit" is statistically lower among those who use supplements than among those who do not use supplements, when considering both the European (13) and American Consensus (12) $(p=0$. 0210 and 0.0098 , respectively) (table 2).

The statistical connections between the CF patient age and the age of diagnosis were not significant when related to FEV1 ( $p=0.4253$ and $p=0.0899$, respectively).

In the analysis of pulmonary function test FEV1, CF patients with FEV1 $<80 \%$ and $A C<5$ th percentile showed association statistically significant $(p=0.0021)$ (table 3$)$.

The average percentage of achievement of the Recommended Dietary Allowances/DRIs (16) among CF patients was of $104.51 \pm 34.53 \%$, below the recommended 120 to $150 \%$. In the study, $72.34 \%$ of the CF patients were below the recommended dietary intake and $19.15 \%$ had an ideal 


\section{TABLE 1}

Description of sex, age, FEV1 and antropometric measures of cystic fibrosis patients on home enteral therapy in Brazil. Period: 2009-2011.

Variable

Sex (male/female)

Age (months), mean \pm sd

Age diagnostic (months), mean \pm sd

TST $\geq$ percentile 5 (frequency, $\%$ )

$<$ percentile 5 (frequency, \%)

AC $\geq$ percentile 5 (frequency, \%)

$<$ percentile 5 (frequency, \%)

Variable

FEV1 \%, mean \pm sd $\mathrm{n}=47$

$28 / 19$

$9.61 \pm 4.2$

$23.33 \pm 33.81$

44(93.62\%)

$3(6.38 \%)$

$36(76.50 \%)$

11(23.50\%)

$\mathrm{n}=37$

$86.80 \pm 22.30$

FEV1 $=$ forced expiratory volume in one second ; Spirometry was performed in children older than 6 years $(n=37)$

$\mathrm{TST}=$ triceps skinfold thickness ; $\mathrm{AC}=$ arm circunference.

TABLE 2

Classification of nutritional status and relationship between pulmonary function and the use of nutritional supplement, enzymatic (PERT) and vitamin in cystic fibrosis patients ( $n=37)$ enteral nutritional in Brazil.Period: 2009-2011.

\begin{tabular}{|c|c|c|c|c|c|c|}
\hline \multirow[t]{2}{*}{ Variables } & \multicolumn{2}{|c|}{$\begin{array}{l}\text { NS European } \\
\text { Consensus }^{13}\end{array}$} & \multirow[t]{2}{*}{ p-value* } & \multicolumn{2}{|c|}{$\begin{array}{l}\text { NS American } \\
\text { Consensus }^{12}\end{array}$} & \multirow[t]{2}{*}{$p$-value* } \\
\hline & $\begin{array}{l}\text { Without deficit } \\
\qquad n=34\end{array}$ & $\begin{array}{l}\text { With deficit } \\
\qquad n=13\end{array}$ & & $\begin{array}{l}\text { Without deficit } \\
\qquad n=34\end{array}$ & $\begin{array}{l}\text { With deficit } \\
\qquad n=13\end{array}$ & \\
\hline \multicolumn{7}{|l|}{ FEV 1} \\
\hline$<80 \%$ & 7(53.85\%) & $6(46.15 \%)$ & & 7(50.00\%) & $7(50.00 \%)$ & \\
\hline$\geq 80 \%$ & $20(86.96 \%)$ & $3(13.04 \%)$ & & $20(86.96 \%)$ & $3(13.04 \%)$ & \\
\hline \multirow[t]{2}{*}{ Missing value } & 7 & 4 & & 7 & 3 & \\
\hline & & & 0.0459 & & & 0.0230 \\
\hline \multicolumn{7}{|l|}{ PERT } \\
\hline Present & $27(69.23 \%)$ & $12(30.77 \%)$ & & $27(67.50 \%)$ & $13(32.5 \%)$ & \\
\hline Absent & $7(100.0 \%)$ & 0 (0.00 \%) & & 7 (100.0\%) & $0(0.00 \%)$ & \\
\hline \multirow[t]{2}{*}{ Missing value } & 7 & 1 & & 7 & 0 & \\
\hline & & & 0.1648 & & & 0.1660 \\
\hline \multicolumn{7}{|c|}{$\begin{array}{l}\text { Supplementation } \\
\text { of vitamins }\end{array}$} \\
\hline Present & $26(70.27 \%)$ & 11(29.73\%) & & $25(65.79 \%)$ & $13(34.21 \%)$ & \\
\hline Absent & 8(88.89\%) & 1(11.11\%) & & 9(100.0\%) & 0(0.00\%) & \\
\hline \multirow[t]{2}{*}{ Missing value } & 0 & 1 & & 0 & 0 & \\
\hline & & & 0.4092 & & & 0.0906 \\
\hline \multicolumn{7}{|c|}{$\begin{array}{l}\text { Nutritional } \\
\text { supplementation }\end{array}$} \\
\hline Present & $21(63.64 \%)$ & $12(36,36 \%)$ & & $20(60.61 \%)$ & 13(39.39\%) & \\
\hline Absent & $13(100.0 \%)$ & $0(0.00 \%)$ & & $14(100.0 \%)$ & $0(0.00 \%)$ & \\
\hline \multirow[t]{2}{*}{ Missing value } & 0 & 1 & & 0 & 0 & \\
\hline & & & 0.0210 & & & 0.0098 \\
\hline
\end{tabular}

*p-value obtained by chi-square; NS= nutritional status; FEV1=forced expiratory volume in one second;

Spirometry was performed in children older than 6 years $(n=37)$; PERT= pancreatic enzyme replacement therapy. 
consumption. The carbohydrate intake was adequate, $\geq 50 \%$, however, the protein intake was high (21.95\%) and lipid one, below the recommended $\geq 35 \%(26.10 \%)$, as described in figure 1.

\section{DISCUSSION}

Over the past 50 years, the longevity in patients with CF has increased significantly and the improvements have been attributed to multiple factors such as early diagnosis, improvements in nutrition, infection control, body mass index (BMI), socioeconomic status, among others $(17,5,18)$.

In this study, the subjects were diagnosed when they were, on average, 23 months old and this result does not corroborate with the surveys performed in the Cystic Fibrosis Reference Center. Chakr et al.(19) and Pereira et al.(20) verified that cystic fibrosis infant patients diagnosed before they were 12 months old, 11,7 and 4,5 respectively.

This result indicates that the neonatal screening should be expanded and effective in Brazil aiming the early diagnosis of this disease, the prevention of pulmonary complications,

\section{TABLE 3}

Anthoropometric characteristics and FEV1 in cystic fibrosis patients ( $n=37)$ enteral nutrition in Brazil. Period: $2009-2011$.

\begin{tabular}{|c|c|c|c|}
\hline Variables & $\begin{array}{c}\text { FEV } 1<80 \% \\
n=14\end{array}$ & $\begin{array}{c}\text { FEV } 1 \geq 80 \% \\
n=23\end{array}$ & $p$-value ${ }^{*}$ \\
\hline Weight (mean \pm sd) & $35.63 \pm 15.74$ & $33.25 \pm 14,09$ & 0.6370 \\
\hline Height $($ mean \pm sd $)$ & $1.44 \pm 0.21$ & $1.36 \pm 0,18$ & 0.2522 \\
\hline BMI (mean \pm sd $)$ & $16.34 \pm 2.91$ & $17.02 \pm 3,23$ & 0.5278 \\
\hline$A C$ & & & 0.0021 \\
\hline$<$ percentile 5 & $7(87.50)$ & $1(12.50)$ & \\
\hline$\geq$ percentile 5 & $7(24.14)$ & $22(75.86)$ & \\
\hline \multicolumn{4}{|l|}{ TST } \\
\hline$<$ percentile 5 & $2(14.29)$ & $0(0.0)$ & 0.1366 \\
\hline$\geq$ percentile 5 & $12(85.71)$ & $23(100.0)$ & \\
\hline
\end{tabular}

\section{FIGURE 1}

Distribution of macronutrients ingested by cystic fibrosis users an enteral therapy program in Brazil. Period: $2009-2011$.

\section{Distribution of macronutrients (\%)}

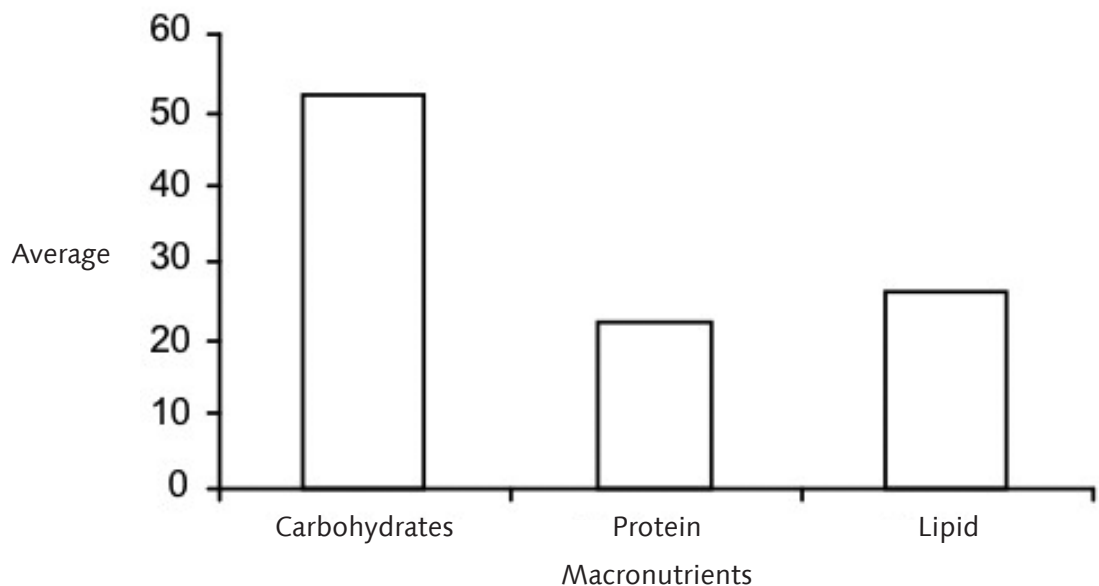


nutritional disorders, and assistance in growth $(18,21)$. In the United States, around 50\% of CF patients have the diagnosis confirmed by completing six months of life (22).

These analysis found low-income and low maternal education among the guardians of patients. Although the literature is scarce in socio-economic data releases from individuals with $C F$, income and maternal education, it is known that a favorable socioeconomic status allows a greater degree of maternal education and higher income and, thus, it contributes directly to a better treatment adherence and better nutritional status. The nutritional profile is directly linked to a better clinical status and fewer number of hospital infections (23). CF patients in the most advantageous economic situation can be better informed and, therefore, get better health care and access to services while in attendance at the clinics.17 Schechter et al., highlighted in a study in the U.S. that the socioeconomic level is associated to 3.6 higher risk of death, and also to a set of harmful environmental factors such as pollution, exposure to passive smoking, individual and familiar stress, besides the lowest values of weight, height and FEV1. The impact proved to be so obvious that the authors considered the socioeconomic profile as a potential confounder in clinical researches (24).

The use of consensuses on clinical evaluation of CF patients is recommended in the literature to ensure an adequate assistance to patients and an effectively prevention and treatment of nutritional failure. Consensuses directed to this population has detected more cases of malnutrition than nonspecific parameters $(12,13,25)$.

Many patients in this study had nutritional deficit and altered pattern of spirometry, a common situation in adolescents and adults with cystic fibrosis, because the nutritional status, body mass, BMI follow the pulmonary function and indicate a better prognosis $(26,27)$. The use of percentile of $\mathrm{BMI}$ in this study is consistent with the literature, because in children over 2 years this indicator is related to adequate growth, besides a lower risk of death (28). A cohort study from 1990 to 2007 showed improvement in survival of CF patients with low pulmonary function when there is monitoring of BMI. Researchers say that these findings may help patients, relatives and teams in the appropriate individual management and inform the managers of public policies about the right time of interventions and allocation of $\mathrm{fi}$ nancial resources (29).

The statistical association found in this survey between the AC and FEV 1 was expected, because it is common the link between pulmonary function decline and loss of muscle mass due to the high energy expenditure of these patients (30). In a prospective cohort conducted with children during 3,5 years, the authors presented results that corroborate with our research, because it was observed an important deficit of lean body mass due to an increase in muscle protein catabolism common in CF (31). Low-cost techniques and of good applicability to body assessment as measures of folds and circumferences are ordinaries in Reference Centers and contribute to the service evaluation as verified by the study of Pereira et al., held in 2010, where values were below $10 \%$ of depletion of adipose and muscle tissue among CF patients indicating good adherence to dietary treatment (20).

When evaluating the association between the enzyme replacement therapy, the use of fat-soluble vitamins and nutritional status were not observed statistically significant results, although the exogenous replacement of enzymes and vitamins is necessary in many cases of CF due to pancreatic insufficiency in $85 \%$ to $95 \%$ of CF patients and excessive loss of lipids that leads to malabsorption of vitamins $A, D, E$ and $K$. Pancreatic sufficient patients become insufficient as they get old and this can be observed by laboratory tests, signs of malabsorption of fats and insufficient weight gain (32-34). Martinez Costa et al. (35) found in a sample of adolescents and children specific deficiencies to the carotenoids (63\%) and vitamin E (47\%). The replacement of fat-soluble vitamin in CF patients can be made by multivitamin designed in the water soluble form due to the difficulty of absorption of these vitamins. However, it should also take care about its use, because they can cause nauseas (32).

CF patients have energy recommendations of 120 to $150 \%$, with high levels of fats (16). To achieve the recommendations provided and improve the nutritional status, nutritional supplements were used in this study, and they showed significant correlation with the nutritional profile of patients ( $p=0.0098)$. The use of polymeric, oligomeric, hypercaloric and hyperlipidic formulas were suggested by the Nutrition Service due to high energy demand observed by the pulmonary disease and enzyme replacement therapy, besides the possibility of accessing and registering on Program of Home Enteral Nutrition Therapy, where the FC patients receive the formulas with no cost which facilitates the use and adherence to treatment, because most of the patients belong to low-income population.

Although patients are users of a Brazilian government program of enteral nutritional therapy, it was noticed a percentage of achievement of DRIs (16) below the recommended intake and profile of ideal lipid consumption was not achieved. The literature is not consensual about the effectiveness of the use of supplements in FC patients, (36) however, its use is recommended for patients with nutritional deficiency, contributing to a higher caloric intake.

Studies that evaluated the dietary intake among CF patients corroborate with the results obtained in this work, where most of the CF patients did not reach the recommendations.

For improvements in the program of enteral nutritional therapy to CF patients, health public policies in Brazil must be planned and restructured to produce improvements in nutritional and clinical assistance, in addition to promoting the prognosis and quality of CF patient's life.

\section{RESUMEN}

El presente estudio evaluó 47 pacientes con fibrosis quística (FQ) con la asistencia de un Programa de Nutrición Enteral Domiciliaria. Se tomaron medidas antropométricas de peso, talla, pliegue del trícipital y circunferencia de cintura y espirometria. Se registraron las enzimas y suplementos de vitaminas solubles en grasa. No encontraron asociaciones con el uso de suplementos de vitaminas y enzimas entre los grupos que teníamos no tenían déficit nutricional. La espirometría de los pacientes "sin déficit nutricional", para el consenso americano y europeo, tiene uma tasa VEF1 $\geq$ $80 \%$ estadísdicamente superior a la tasa de VEF1 < $80 \%$ (0.0459 y 0.0230 , respectivamente).La tasa de pacientes com FQ "sin déficit nutricional" y usando suplementos fue estadísticamente más bajos que los que no usaban, cuando se consideran los dos consenso $(p=0.0210$ y 0.0098 , respectivamente). La prueba de función pulmonar de los pacientes con FQ com VEF $1<80 \%$ y circunferencia del brazo < percentil 5 mostraron una asociación estadísticamente significativa $(p=0.0021)$. Las asociaciones entre déficit nutricional y espirometría se encontraron muy frecuentemente 
entre los pacientes con FQ.

Palabras clave: Fibrosis quística, enfermedad pulmonar, estado nutricional, tamizaje neonatal, espirometría.

Acknowledgments: We would like to thank the support given by the Health Secretary of the Federal District and the Multidisciplinary Team Care in Cystic Fibrosis from Base Hospital of Brasilia, FD.

\section{REFERENCES}

1. Rosenstein BJ, Cutting GR. The diagnosis of cystic fibrosis:a consensus statement. Cystic Fibrosis Foundation Consensus Panel. J Pediatr 1998; 132:589-95.

2. Konstan MW, Butler SM, Wohl ME, Stoddard W, Matousek $R$, Wagener JS, et al. Growth and nutritional indexes in early life predict pulmonary function in cystic fibrosis. $J$ Pediatr 2003;142:624-30.

3. Ranganathan SC, Parsons F, Gangell C, Brennan S, Stick $S M$, Sly PD. Evolution of pulmonary inflamation and nutritional status in infants and young children with cystic fibrosis. Thorax 2011;66:408-13.

4. Word Health Organization. The molecular genetic epidemiology of cystic fibrosis. Report of a joint meeting of WHO /ECFTN/ICF(M)A/ECFS. Genova, Word Health Organization, 2002.

5. Dodge JA, Lewis PA, Stanton M, Wilsher J.Cystic fibrosis mortality and survival in the UK: 1947-2003. Eur Respir J 2007; 29: 522-6.

6. DISTRITO FEDERAL. Secretaria de Estado de Saúde. Portaria $n^{\circ}$ 94, de 20 de maio de 2009. Regulamento técnico para fornecimento de fórmulas para fins especiais para atendimento domiciliar no âmbito do Distrito Federal. Disponível em: http://www.buriti.df.gov.br)

7. Rocha SY. Sistema Único de Saúde: avaliação e perspectivas. Saude e Soc.1994; 3:3-10. Disponível em: <http://www. scielo.br/scielo

8. DISTRITO FEDERAL. Secretaria de Estado de Saúde. Lei $n^{\circ}$ 4.190, 06 de agosto de 2008. Assegura a todas as criancas nascidas nos hospitais e demais estabelecimentos de atenção à saúde de gestantes da rede pública de saúde do Distrito Federal o direito ao teste de triagem neonatal, na sua modalidade ampliada. Disponível em: http://www. buriti.df.gov.br

9. Farrel PM, Rosenstein BJ, White TB, Accurso FJ, Castellani $C$, Cutting GR, et al. Guidelines for diagnosis of cystic fibrosis in newborns through older adults: cystic fibrosis foundation consensus report. J Pediatr 2008; 153:4-14.

10. World Health Organization- Expert Committee on Physical Status: the use and interpretation of anthropometry. Technical Report Series 854. Genova: WHO; 1995.

11. World Health Organization WHO. Onis M, Onyango AW Borghi E, Siyam A. Nishida C, Siekmann J. Development of a WHO growth reference for school-aged children and adolescents. Bull World Health Organization; 2007: 660-7.

12. Borowitz D, Baker RD, Stallings V. Consensus report on nutrition for pediatric patients with cystic fibrosis. J Pediatr Gastroenterol Nutr. 2002:35: 246-59.

13. Sinaasappel $M$, Stern $M$, Littlewood J, Wolfe S, Steinkamp $G$, Heijermen HGM, Robberecht E. Nutrition in patients with cystic fibrosis: a European consensus. J Cystic Fibrosis 2002; 1: 51-75.

14. Rodrigues JC, Cardieri JMA, Bussamra MHCF, Nakaie CMA, Almeida MB, Silva Filho LVF et al. Provas de Função Pulmonar em crianças e adolescentes. J Pneumol. 2002;
28(3): 207-21.

15. ATS. American Thoracic Society. Standardization of spirometry - 1994. Am J Respir Crit Care Med 1995; 152:1107-36.

16. IOM - Institute of Medicine. DRI Dietary reference intakes for energy, carbohydrate, fiber, fat, fatty acids, cholesterol, protein, and amino acids. Washington (DC): National Academy Press, 2005.

17. Barr HL.Association between socioeconomic status, sex and age at death from cystic fibrosis in England and Wales (1959 to 2008):cross sectional study. BMJ 2011; 343: $d 4662$

18. Cystic Fibrosis Foundation Patient Registry: annual data report 2009 . Bethesda (MD): Cystic Fibrosis Foundation, 2011.

19. Chakr VCBG, Silveira MR, Vendrusculo FM, Leites $G T$, Donadio MVF, Paim TF et al. Descriptive analyses of cystic fibrosis patients followed by the Pediatric Pulmonology Unit of a university hospital in Porto Alegre-RS.Scientia Medica 2006;16:103-8.

20. Pereira JS, Forte GC, Simon MISS, Drehmer M, Behling EB. Nutritional Status in patients with cystic fibrosis in a specialized centre in south Brazil. Rev HCPA 2011; 31(2): 131-7.

21. Farrel PM. Nutritional benefits of neonatal screening for cystic fibrosis. New Engl J Med 1997; 337:963-9.

22. Ratjen F. Doring G. Cystic Fibrosis. Lancet 2003; 361:6819.

23. Pinto ICSP, Silva CP, Britto MCA. Perfil nutricional, clínico e socioeconômico de pacientes com fibrose cística atendidos em um centro de referência no nordeste do Brasil. J Bras Pneumol 2009; 35 (2): 137-43.

24. Schechter MS, Shelton BJ, Margolis PA, Fitzsimmons SC. The association of socioeconomic status with outcomes in cystic fibrosis patients in the United States. Am J Respir Critical Care Medicine 2001;163:1331-7.

25. Morlin C, Gomes LS, Morsoletto RHC, Pereira LC. Nutritional profile of patients with cystic fibrosis in a public hospital in Uberlândia - Minas Gerais. Rev Bras Nutr Clin 2006; 21(1): 12-6.

26. Ziegler B, Rovedder PME, Dalcin PTR, Menna-Barreto SS. Respiratory patterns in spirometric tests of adolescents e adultos com fibrose cística. J Bras Pneumol. 2009; 35(9):854-9.

27. Hollander FM, Roos NM, Vries JHM, Berkhout FT. Assessment of nutritional status in adult patients with cystic fibrosis : whole-body bioimpedance vs body mass index, skinfolds, and to leg-to-leg bioimpedance. J Am Diet Assoc. 2005; 105(4)549-56.

28. Salvatore $D$, Buzzetti $R$, Baldo $E$, Forneris MA, Lucidi $V$, Manunza $D$ et al. Overview of international literature from cystic fibrosis registries. Neonatal screening and nutrition growth. J Cystic Fibrosis 2010; 9:75-83.

29. George $P M$, Banya $W$, Pareek N, Bilton D, Cullinan P, Simmonds NJ. Improved survival at low lung in cystic fibrosis: cohort study from 1990 to 2007. BMJ 2011; 28: 342.

30. Chaves CRMM, Britto JAA, Oliveira CQ, Gomes MM, Cunha ALP. Association between nutritional status measurements and pulmonary function in children and adolescents with cystic fibrosis J Bras Pneumol 2009; 35 (5): 409-14

31. Adde FV, Rodrigues JC, Cardoso AL. Nutritional follow-up of cystic fibrosis patients: the role of nutrition education. J Pediatr 2004; 80(6):475-82. 
32. Clinical Guidelines: Care of children with cystic fibrosis. Royal Brompton Hospital \& Harefield NHS Trust. United Kingdom, 2011. [Acesso 2011 September 02] Disponível em: www.rbht.nhs.uk/childrencf).

33. Walkowiak J, Nousia-Balassopoulou A, Witt M, Herzig $K H$. Longitudinal follow -up of exocrine pancreatic function in pancreatic sufficient cystic fibrosis patients using fecal elastase-1 test. J Pediatr Gastroenterol Nutr. 2003; 36:474-8.

34. Wooldridge J. EUR -1008 pancreatic enzyme replacement is safe and effective in patients with cystic fibrosis and pancreatic insufficiency. J Cystic Fibrosis 2009; 8:405-17.

35. Martinez-Costa C, Escribano A, Nunez Costa F, GarcíaMaset L, Luján L, Martinez-Rodriguez L. Nutritional intervention in children and adolescents with cystic fibrosis. Relationship with pulmonary function. Nutr Hosp 2005; 20(3):182-8.

36. Rosalind SL, Sarah W. Oral calorie supplements for cystic fibrosis. Cochrane Database of Systematic Reviews. In: The Cochrane Library 2010. 